sponte circa Gissam nascentium" which gained for him a considerable reputation. The knowledge he showed of cryptogams induced William Sherard to persuade him to come to England mainly to help with the "Pinex" he had undertaken on Tournefort's advice. When Sherard died he left an endowment to found a chair of botany at Oxford stipulating that Dillenius should be its first occupant. The drawings now received cover the whole period of Dillenius's activities, and include a set of copies from published works apparently made in his student days; the coloured figures of the fungi described in the Giessen catalogue; drawings of garden plants from Giessen; those in the third edition of Ray's "Synopsis" (which Dillenius edited) and many prepared and not used; plants found on a Welsh tour in 1726 ; about 200 of plants growing in the Oxford Botanic Garden, 1744-46 ; "Junci and Gramina". Most of the material which Vines and Druce mention in "The Dillenian Herbarium" (1907) as having passed into the hands of Prof. Humphrey Sibthorp and eventually disappearing and being "no doubt irrevocably lost" has thus come to light. The drawings show that Dillenius ranks much higher as a botanical artist than was generally thought. It would be highly satisfactory if the numerous letters received by Dillenius from botanical correspondents could be similarly retrieved.

\section{Astrophysical Monographs}

A valuabLe new series of monographs on astrophysical subjects is being planned by the University of Chicago Press under the auspices of the Astrophysical Journal, the editorial board of this journal serving in a similar capacity for the new series. Each monograph aims at being an exhaustive, comprehensive summary of a limited field written by an authority on the subject, and the whole should form a growing library of great use to astronomers and advanced students. In the first monograph ("The Distribution of the Stars in Space". Sup. Roy. 8vo. Pp. xvi+124. Chicago: University of Chicago Press; London : Cambridge University Press, 1937. 11s. 6d. net), Prof. B. J. Bok deals with stellar statistics and galactic structure, dividing his subject into three sections-the methods of analysis, the data of observation, and problems of galactic structure. In the first section a fuller treatment of the earlier mathematical methods, especially those developed by Charlier and others, would have been welcomed by many if the space had been available, but the necessary condensation has not impaired either the general sequence or elarity of this very readable mathematical section. It has had also the advantage of allowing more complete and critical accounts of modern numerical methods of analysis and their application to determining the distance and absorbing power of a dark nebula. The second section gives a useful summary of the relevant data of observation, and indicates where the need for further observations arises, while the last section deals with general problems of galactic structure of a more or less controversial nature. Although his own views are freely expressed, the author succeeds in giving an impartial and stimulating account of the subject, together with some tentative conclusions suggested as working hypotheses to encourage further observational studies.

\section{History of Chemistry}

WE have received a pamphlet by Prof. E. Pietsch, editor-in-chief of Gmelins Handbuch der anorganischen Chemie, which is entitled "Sinn und Aufgabe der Geschichte der Chemie". This is published by Verlag Chemie, Berlin, price 1 mark. Prof. Pietsch shows in a very convincing way the great utility of a study of the history of chemistry in the education of young chemists. He deals with the subject in its cultural aspects and makes clear how such a study can do much to remove the dangers of over-specialization now threatening chemists in the enormous development of minute detail which is occurring in the science. He also shows that a knowledge of past problems can lead to a great economy of time and effort, since in many cases large amounts of time and trouble have been expended on matters which have been fully dealt with before but forgotten. A knowledge of the history of applied chemistry also has a distinct commercial value, examples of which are given. The text includes a very brief but surprisingly complete sketch of the history of chemistry taken as a whole, with its great periods of development. The pamphlet is characterized by a maturity and a philosophical outlook which recommend it to all thoughtful students of science; and to chemists in particular it should prove stimulating and suggestive.

\section{Midland Naturalists' Union}

REPRESENTATIVES of natural history societies in the Midlands meeting in the rooms of the Birmingham Natural History and Philosophical Society on June 18 unanimously decided to form a Midland Naturalists' Union, membership of which is open to natural history, archæological and similar societies in the counties of Monmouth, Hereford, Worcester, Warwick, Leicester, Rutland, Nottingham and Lincoln. It is intended to organize an annual congress, several field meetings and, in larger towns, a number of lectures during the winter months. A list of lecturers willing to visit societies, a panel of referees for specimens and information in the various groups of plants and animals and other branches of natural history and archæology, and a system of lantern slide exchange among members, are also being organized. It is felt that the Union will facilitate co-operative work among the societies as well as bring workers into touch with others in their own branches of the subject. Further information may be obtained from the honorary secretary, G. Brian Hindle, 55 Newhall Street, Birmingham.

\section{"Dechema"}

The annual meeting of the "Dechema" held in Berlin at the end of April was attended by about 500 people, a testimony both to the interest attached to chemical engineering subjects and to the organizing energy of its director, Dr. Bretschneider. Three reports dealt with standardization, one having relation to technical terms, another to drawings and a third to corrosion from the point of view of rendering 